\title{
The primary goal of monetary policy: reflections on the nature of the problem
}

\author{
Adam HETMAŃCZUK \\ WSB University in Wroclaw, Poland
}

Received: 08.03.2017, Revised: 21.02.2021, Revised: 22.03.2021, Accepted: 23.03.2021

doi: http://dx.doi.org/10.29015/cerem.441

Abstract:

Aim: In this article, the state of the discourse concerning the final goal of the modern central bank is presented, in particular the aim of price stability, understood as low and stable inflation.

Design/Research methods: The article was prepared on the basis of scientific publications in the field of monetary policy as well as materials and documents from different central banks, including the US Federal Reserve System and the European Central Bank.

Conclusions/findings: Low and stable inflation reduces uncertainty about future price developments. This facilitates decision-making for companies concerning production and investment, and for households concerning consumption and saving. From a macroeconomic point of view, price stability is a prerequisite for the efficient functioning of the economy and for achieving high growth rates. In practice, the need for a quantifiable definition has been disregarded, while only a descriptive and qualitative definition of price stability is insufficient for an effective monetary policy and the implementation of the anti-inflationary mission by the central bank.

Keywords: central bank, monetary policy, price stability, inflation JEL: E31, E51, E52, E58

Correspondence address: Adam HETMAŃCZUK, WSB University in Wrocław, ul. Fabryczna 29-31, 53609, Wrocław, Poland. E-mail: adam.hetmanczuk@wsb.wroclaw.pl 
"Stable prices promote long-term economic growth by allowing households and firms to make economic decisions and undertake productive activities with fewer concerns about large or unanticipated changes in the price level and their attendant financial consequences. [...] achieving price stability is not only important in itself; it is also central to attaining the Federal Reserve's other mandated objectives of maximum sustainable employment and moderate long-term interest rates."

\section{Ben Bernanke, 15 February 2006}

(from: Semiannual Monetary Policy Report to the Congress)

\section{Introduction}

The mission and the goal of a central bank in the period preceding the outbreak of the first financial mega-crisis, i.e. in the decade opening the $21^{\text {st }}$ century, used to be defined transparently and reliably from the perspective of all market players. There was no need to modify them by any means whatsoever. For years, monetary policy had been successfully implemented as a means to efficiently pursue the strategy of direct inflation targeting (DIT). One of key elements of this modern and multi-parametric strategy is that price stability is considered as the primary goal of monetary policy. Its second and equally significant constituent is the public announcement of a numerical inflation target, namely quantification of price stability as the central bank's most important goal (Duisenberg 2001).

In a distant past, as a means to deploy intermediate monetary strategies, ensuring price stability was not always possible, hence in some cases such strategies were abandoned. A good example is the money supply control strategy. This was particularly popular in the 1970's and 1980's among central banks of highlydeveloped economies. It was implemented by central banks operating in such countries as the United States of America, the Federal Republic of Germany, the United Kingdom and Switzerland. Under this policy, monetary authorities would maintain an increase of money supply in the economy at a pre-defined level which was assumed to contribute to inflation stabilization (Goodfriend 2007). A suitable example to mention in this respect is the classical principle of monetary base: Friedman's k-percent rule (Friedman 1969). However, implementation of this policy gave rise to numerous difficulties. It is commonly known that the price level in market economy, and particularly in one which is widely open to exchange with the 
external environment, is affected by a number of factors. This has as a consequence that the mere increase of money supply does not necessarily translate directly into an inflation rise (Rhys, Barry 1976). Consequently, even when the money supply increase conform with the central bank's objective, this not always would it lead to the intended inflation level, since it might be strongly affected by a wide range of factors. This is the reason why implementation of this strategy was abandoned. Gerald Bouey, a former governor of the Bank of Canada, once said, "We didn't abandon the monetary aggregates, they abandoned us" (The Economist 2006).

The pursuit of the direct inflation targeting strategy coincided with a very beneficial situation in the global economy. Time had proved to be a valuable ally to central banks. In many aspects, it was a particularly beneficial period for the global economy, commonly referred to as the Great Moderation, lasting from mid-1980's until the first decade of the $21^{\text {st }}$ century (Bernanke 2004). Institutions decisive of how monetary policy was molded, which gained actual independence in many countries, mastered the art of ensuring price stability far more effectively, and they would often achieve this goal by means of the DIT strategy. For a certain period of time, one might even have a misleading yet absolutely desirable impression that it was the end of economic cycles, and that a merger of constant long-term growth with low inflation would become realistic (Eckstein, Sinai 1986).

The external environment (stakeholders such as commercial banks, financial intermediaries, households, entrepreneurs, investors and shareholders) experienced no major problems accepting the message given by the central bank, since its content was clear and transparent, and raised no doubts among addressees. Moreover, the message was simple: to keep inflation under control by undertaking adequate actions in line with the strategy adopted, ensuring high efficiency of monetary policy. Neither did it require extended interpretation of law, nor any additional commentary to be provided by monetary authorities. Furthermore, in the meantime, no major and significant reasons and factors occurred to even consider potential revision of the solution previously adopted, not to mention taking its radical alteration into consideration. In this area, the central bank would follow a very simple principle: there are no strong stimuli to changes, and so there will be none. Not even once did it find itself in an extreme situation which would force it to 
display some extraordinary creativity in the implementation of monetary policy, where it would be forced to resort to using unconventional instruments. At that period of time, constant economic growth was attained without any inflation pressure, and central banks were forced to change interest rates only to a very limited degree. It was simply unreasonable to "fix" what was working perfectly (Ciżkowicz-Pękała, Grostal 2019).

Price stability was approved and accepted as the fundamental goal of monetary policy by a decided majority of central banks all over the world. Its transparent interpretation as a process of maintaining low and stable medium-term inflation quickly became commonly acceptable as well. Keeping prices stable is the best contribution central banks can make to improving people's individual welfare. High inflation can lead to a spiral of increasing prices. The negative consequences of deflation are felt by everyone. Long periods of excessive inflation or deflation have negative effects on the economy. In spite of appearances, deflation is sometimes more dangerous for the economy and society than inflation. The macroeconomic implications of deflation are well known. The expectation of falling prices delays purchases and investment. The combination of falling output prices and downwardly rigid nominal wages damages the profitability of businesses and reduces the demand for labour. Deflation means that the real burden of nominal debt increases over time, making debt repayments more difficult for households, firms and governments. Whereas stable prices help to ensure that the economy is growing, jobs are safe and everyone can feel confident that the money in their pocket will be worth roughly the same tomorrow as it is today. This article contains a reflection on the choice of the goal of monetary in the context of the definition and meaning of price stability, in the context of economic changes during the last decade.

\section{Choice of the goal of monetary policy}

For several decades now, the monetary policy implemented by central banks of the most important economies in the world has been focused on the pursuit of its fundamental goal, i.e. attaining and maintaining low and stable medium-term 
inflation. One should note that goals of monetary policy evolved as time passed, and the preferred orientation of these evolutionary changes was considerably affected by the theories considered predominant at the given time. Generally, they were Keynesianism or Monetarism (Przybylska-Kapuścińska 2008). Ultimately, the fact that it is none other than low inflation which has become the most important purpose of monetary policy is caused by practice rather than by theory. What settled that matter in the past was, among other factors, the developments taking place in market economies in the 1970 's, i.e. prices increasing continuously and very dynamically. Many countries around the globe faced the challenge of high and long-lasting inflation in those times. The prestigious and influential British weekly magazine, The Economist, highlighted supply factors as those which strongly drove the inflation then, mainly the increase of energy costs, and primarily the rapidly growing petroleum prices caused by the first and the second oil shock. This was a clear example of cost-push inflation, which has been described as follows: "Inflation in the 1970's was largely driven by increases in energy costs, and especially by increases in the price of oil. The first oil shock, in 1973, sent consumer price inflation from around $4 \%$ to near $9 \%$, but headline inflation thereafter fell back to 5\%. Crisis hit again in 1979, and from 1978 to 1980 annual consumer price increases rose from just over 6\% to near 15\%" (The Economist 2010). It was Paul A. Volcker who helped to shape American economic policy for decades, notably by leading the Federal Reserve's brute-force campaign to subdue inflation in the 1970s and 1980s. Volcker as Federal Reserve chairman in the early 1980s raised interest rates to historic highs and triggered a recession as the price of quashing double-digit inflation. He was called the Inflation-Killer/Inflation-Buster. Volcker adhered to an unpopular view: "Things had to get worse before they could get better." Paul Volcker died on December $8^{\text {th }} 2019$ at the age of 92 (Lowenstein 2019).

Consumer price indices were rapidly rocketing. And so in the aftermath of the first oil shock, in the USA they went up by almost as much as $125 \%$, i.e. from 4 to nearly $9 \%$. After a temporary, relatively large drop, they glided up high again. The relative increase was nearly $150 \%$ when the next oil shock happened. The consequence of the oil shocks of 1973 and 1979 was stagflation (= stagnation + inflation), being a combination of high inflation and recession perceived as very 
dangerous to the economy (Roubini, Mihm 2011). Economists tend to seek the reasons for that phenomenon in the negative supply shock which triggers both the price increase and production limitation or reduction. The term stagflation was coined in 1965 at a Parliament speech of a British politician, Ian N. Macleod, member of the Conservative Party. However, it was not until the times of the first oil crisis that this notion had grown in importance. One of the most interesting stagflation cases was reported in the American economy throughout the two-year period of 1974-1975. In March 1975, the US industrial production output dropped by nearly $13 \%$, while at the same time, the annual consumer price index increased by ca. $12 \%$. A similar situation was observed in 1979, when a significant decline in the economic activity coincided with the inflation rising abruptly. By December of that year, the annual industrial production output growth dropped nearly to zero, while inflation exceeded 13\% (Bronfenbrenner 1976).

There is no consensus among economists on the causes of stagflation. Different economic schools offer their own view on its origins. For example, the supply shock theory suggests that stagflation occurs when an economy faces a sudden increase or decrease in the supply of a commodity or service, such as a rapid increase in the price of oil. In such a situation, prices surge, making production costlier and less profitable, thus slowing down or leading to negative economic growth. Another theory states that stagflation can be a result of poor economic policy. The government can create a policy that harms industries while the money supply increased too quickly (see Bruno, Sachs 1985; Barsky, Kilian 2002, 2004).

In 1975 the inflation rate in the United Kingdom was above 24\%, whereas it exceeded $11 \%$ in USA, while a similar state of matters was observed in other countries. The average inflation rate calculated for the OECD states in the 1970's had a double-digit value (10.2\%), and in the first half of the next decade, it was only one percentage point lower (9.2\%). For instance, in 1981, among 30 OECD countries, only two reported their inflation to be below 5\%, whereas the group's average was $10.5 \%$. For the sake of comparison, twenty five years later, i.e. in 2006, as many as 25 OECD countries reported inflation rate below 5\%, whereas the average rate of price increase equaled 2.2\% (Blanchard 2011). Inflation was commonly proclaimed as public enemy no. 1 , and a process of combatting it was 
initiated, soon to appear as particularly tedious and requiring as much determination as time. The great inflation (meaning: The Great Inflation of the 1970s) changed the perception of the central bank and the monetary policy it implemented. "The central bank's role, as it is commonly acceptable nowadays, is the heritage of two most catastrophic economic crises of the previous century, i.e. the Great Depression of the 1930's and the great inflation of the seventies" (Harris 2008: 153). At this point, it should also be emphasized that the accelerated inflation of the turn of the 1970's and 1980 's had greatly contributed to overcoming the 40 years long hegemony of Keynesism and facilitated the expansion of monetarist counter-revolution in the theory of economics (Snowdon et al. 1998).

In the 1970's as well as in the first half of the next decade, the fight against inflation was promoted to one of the main tasks performed by central banks in highly developed countries. It was then that a consistent pursuit of the anti-inflation mission became the imperative, and other objectives of general economic and monetary nature ceased to be perceived as priorities, and consequently faded into the background. The period of struggle against inflation gave rise to explicit definition of the central bank's fundamental goal. Mastering inflation and maintaining it under control attained the status of a systemic project. The motivations to apply such a solution were not merely of historical nature, dating back to not so distant past, but also stemmed directly from theoretical analysis. Correct functioning of a market economy dominated by high and persistent inflation is simply impossible, since the information function of prices is heavily disturbed under such conditions, and the entire mechanism of "distribution" and utilization of the means of production works in a distorted manner. Consequently, waste is observed across the entire economy. Only by bringing inflation to a low level and consistently striving to maintain its previously moderate dynamism, the central bank is able to create monetary conditions enabling the economy to attain a high rate of growth in the long-term. Therefore, the superior goal of monetary policy was defined as stability of the general level of prices perceived as an emanation of inflation considered civilized, i.e. brought down to a generally acceptable level with the price expectations being relatively permanently anchored. It is then that the central bank's policy may indeed by efficient. 
Robert Lucas (1972) ${ }^{1}$, one of the originators and advocates of the theory of rational expectations, claimed already in 1972 that attaining low inflation was far easier when the price expectations of economic entities were also anchored at a low level. It is common knowledge that future inflation depends to a large extent on the nature of the current inflation-related expectations based on which economic entities make their decisions pertaining to such matters as, for instance, price and remuneration levels. Therefore, one of the most efficient methods of long-term inflation controlling is stabilizing the inflation expectations of the market. They constitute the main driving force of the contemporary inflation processes. The phenomenon of central banks using what is referred to as the nominal anchor is exactly assumed to serve the purpose of bringing inflation expectations to the intended level and maintaining them on such a level for as long as possible. On the other hand, the more stable the current inflation is, and the lower the inflation expectations are as a result of the foregoing, the lesser the concerns about an unexpected rise of inflation in the future. On account of the struggle against inflation, price stability proved to be a natural candidate to be "nominated" the central bank's strategic task. The discussion on the choice of the best goal of monetary policy eventually ended with a consensus: price stability defined using the categories of the rate of inflation changes on an annual basis became the primary goal of contemporary monetary policy.

In the first half of the 1990's, there were countries, such as the United Kingdom, Canada and New Zealand, which adopted specific legislative solutions, emphasizing price stability as the most fundamental goal of monetary policy. This choice was based on a number of grounds, including the past experience of countries where low inflation rates were reported in a longer time horizon. These included mainly Germany and Switzerland. At this point of the consideration, it should also be

\footnotetext{
${ }^{1}$ R. Lucas, winner of the Nobel Memorial Prize in Economic Sciences (1995); as a President of the American Economic Association, at the $151^{\text {st }}$ assembly of that organisation held on 4 January 2003, he delivered a speech (The presidential address to the American Economic Association) presenting an extremely bold and risky hypothesis that the key problem of macroeconomics, namely prevention of recessions, had already been solved, and that no more crises were to be expected. He was terribly wrong though, since five years later the first global economic mega-crisis broke out (15 September 2008 saw the spectacular collapse of the Lehman Brothers investment bank).
} 
mentioned that many American economists would refer to cases of countries where low and stabilized inflation had been observed in order to persuade congressmen to enact suitable regulations. For instance The Federal Reserve Act as amended in 1977 directs the Federal Reserve to pursue monetary policy to achieve the goals of "maximum employment, stable prices and moderate long-term interest rates" (Steelman 2011: 1).

\section{Price stability. Definition and meaning}

It may seem that price stability is a comprehensible notion by the very essence, and that its practical interpretation should not pose any problems, not only to experts but also to members of the general public. However, it is not as simple as it seems. The question is whether defining it from the qualitative perspective only, reinforced by concise characterization, is precise enough and sufficient to proceed to the application phase. Or is it rather indispensable to define price stability using purely quantitative categories, making it possible to use instruments of descriptive or even mathematical statistics? One should at least decide how to express it: for instance, in the form of price rate changes or changes in the price level itself. If the chosen alternative is the price change indicator, how is it to be calculated and using what data? Some possible options include the consumer price index, the wholesale price index, the GDP deflator or the selected components of the latter (e.g. for consumption). There are numerous questions which require answering. However, a decided majority of them does not comprise the subject of this article.

In the quantitative dimension, price stability used to be understood as equivalent to low inflation, e.g. of less than ten per cent per annum (Fischer 1984; Bernanke 2002; Svensson 1999). It is important to have a clear definition and meaning of price stability in the context of monetary policy. For instance, in 1998 the ECB Governing Council formulated the quantitative definition of price stability: "Price stability is a year-on-year increase in the Harmonized Index of Consumer Prices (HICP) for the euro area of below $2 \%$. Price stability must be maintained over a medium-term perspective" (ECB 2016). In addition, in May 2003 the Governing 
Council also clarified that, in the pursuit of price stability, it aims to maintain inflation rates "below, but close to, $2 \%$ over the medium term" (Banco de Portugal 2017). Price stability contributes to achieving high levels of economic activity and employment by improving the transparency of the price mechanism. Under price stability people can recognize changes in relative prices without being confused by changes in the overall price level. This allows them to make well-informed consumption and investment decisions and to allocate resources more efficiently (White 2006).

In most cases, however, the matter of price stability in the economy was addressed rather generally, often without properly assigning a specific numerical value. The very stage of quantification, i.e. characterizing this category in quantitative terms was not considered particularly important. Former Federal Reserve Chairman Alan Greenspan famously defined price stability in qualitative terms as a situation in which "...households and businesses need not factor expectations of changes in the average level of prices into their decisions" (Greenspan 1994). The most significant aspect was the idea, and the quantitative dimension was considered of secondary relevance, since the term low inflation was regarded as sufficient, even though it was glaringly overgeneralized. In certain terms, the said low level of inflation is actually a conventional category, entailing methodological and practical difficulties in measuring the phenomenon itself. One danger is that low inflation that persists over the longer term provides only a small buffer against deflation: if inflation is low, it only takes a relatively small shock to tip the economy into deflation. The macroeconomic implications of deflation are well known. The expectation of falling prices delays purchases and investment. The combination of falling output prices and downwardly rigid nominal wages damages the profitability of businesses and reduces the demand for labour. Deflation means that the real burden of nominal debt increases over time, making debt repayments more difficult for households, firms and governments.

In 1995, the US Senate established a special commission appointed the task of examining the method used for calculating consumer price indices (The Advisory Commission to Study the Consumer Price Index or The Boskin Commission). Its head was professor Michael Boskin, who also chaired the team of economic 
advisors to President George H. W. Bush in the years 1989-1993. On $4^{\text {th }}$ December 1996), the Commission published its final report entitled Toward a More Accurate Measure of the Cost of Living, where it was claimed that the official Consumer Price Index (CPI) had been inflated in 1996 by ca. $1.1 \%$ on the annual scale, and in preceding years - by ca. $1.3 \%$ (Gadomski 2014). The foregoing implies that the actual inflation is usually lower than suggested by the calculations performed, independent of the measurement method applied (aggregate price index according to the formulas by Laspeyres, Paasche, or averaged Fisher's price index).

What has become the most significant element in the discourse on price stability is the central idea. In this respect, one may refer to the famous credo of the German Federal Bank (Deutsche Bundesbank), coined at the end of the 1970's by the then President of Buba, ${ }^{2}$ Otmar Emminger (1977-1979): "Preisstabilität ist nicht alles, aber ohne Preisstabilität ist alles nichts" ("Price stability is not everything, but without price stability, everything is nothing.”) (Schneider 2007). How succinct and, at the same time, accurate statement it is, even though it does not directly mention any value of the indicator describing price dynamics. It should be noted that many solutions concerning the statute and functions of the European Central Bank (ECB) as well as the European System of Central Banks (ESBC) were being patterned after the concepts already applied for some time by the central bank of the Federal Republic of Germany, and especially those applicable to the broad scope of independence of this institution of public trust, for instance, the bank's considerable financial independence, the procedure under which the bank's authorities were appointed and the principles of tenure of the bank's decision making bodies (National Bank of Poland 2004). The German central bank was always considered as the role model for other monetary authorities. What seems particularly meaningful in this respect is the observation made by Jacques Delors (1992), President of the European Committee between 7 January 1985 and 24 January 1995:

\footnotetext{
${ }^{2}$ Economists and analysts interested in how central banking functions often use the acronym Buba to describe the German Central Bank (Deutsche Bundesbank). It was derived from the opening two letters of the two words forming the federal bank's official name - $\underline{\text { Bundesbank. }}$
} 
"Nicht alle Deutschen glauben an Gott, aber alle glauben an die Bundesbank. [...] Die Behörde hat sich weltweit ein Ansehen erarbeitet, wie kaum eine andere. Ihrer Politik ist es zu verdanken, dass sich die D-Mark einst zu einer der stabilsten und renommiertesten Währungen der Welt entwickeln konnte" (Teutsch 2007).

("Not all Germans believe in God, but all believe in the Bundesbank. [...] The Monetary Authority has won a worldwide reputation like no other. Thanks to its policy D-Mark was once able to develop into one of the most stable and renowned currencies in the world.”)

There are many definitions and descriptions of price stability, and they are basically similar or at least very convergent in terms of the actual content, with the differences between them remaining in the sphere of semantics. They usually differ as to the degree of generality or the extent of the characteristics provided for the category itself. The foregoing provides grounds for different interpretations. In spite of that, they still provide a very satisfying object of analysis for experts. Some of the definitions and descriptions of price stability are discussed below.

A definition of price stability which gained popularity among central banking specialists was proposed in 1996 by the contemporary chairman of the Board of Governors of the Federal Reserve System, A. Greenspan, who performed this function for five consecutive terms of office starting from 11 August 1987. "Price stability is that state in which expected changes in the general price level do not effectively alter business and household decisions" (Greenspan 1996). It is indeed concise and provides interesting economic content. This one-sentence characterization of price stability operates with categories of inflation expectations and their potential impact on the behaviour of two groups of economic entities. For A. Greenspan, price stability is equivalent to a state of the economy where the expected changes in the general price level do not actually affect the decisions made by entrepreneurs and households. One may only conclude that price stability, according to the interpretation of the American central bank guru, means the expected inflation being low, and most probably corresponding to weak dynamism of creeping inflation, to the point that, on account of its negligible potential for disturbing the level and the structure of prices and the possible acceleration of processes of currency depreciation, it cannot trigger any considerable change to the decisions and the arrangements already made by market players. In other words, 
price stability is such an actual situation where no one is anxious about the power of inflation and its disruptive impact on the course of economic processes. In practice, there is no mention of anticipation of a discernible price increase, for it will most probably be insignificant, and therefore potentially acceptable. Despite the simplicity and the synthetic nature of the definition proposed by A. Greenspan, its operational applicability is inconsiderable, as it lacks the element of quantification. To recapitulate the foregoing consideration, it should be noted that price stability, as interpreted by A. Greenspan, means a price level being stable enough to prevent the expectations concerning its change from becoming the main factor taken into account while making key economic decisions by those who participate in economic processes.

Merely two weeks after taking a new office (1 February 2006) as the chairman of the Board of Governors of the Federal Reserve System of the United Stated of America, on 16 February 2006, B. Bernanke delivered the Semiannual Monetary Policy Report to the Congress before the United States Senate Committee on Banking, Housing and Urban Affairs. It is then that he also made a comment on price stability and its role in the performance of the American central bank's mandate: "Stable prices promote long-term economic growth by allowing households and firms to make economic decisions and undertake productive activities with fewer concerns about large or unanticipated changes in the price level and their attendant financial consequences. [...] Achieving price stability is not only important in itself; it is also central to attaining the Federal Reserve's other mandated objectives of maximum sustainable employment and moderate long-term interest rates" (Bernanke 2006b). It should reminded that it is the very quotation which opens this article as its keynote. Chairman Bernanke stressed the contribution of stable prices to the promotion of long-term growth. Economic entities, such as entrepreneurs and households, pursue their objectives without fearing about the potential occurrence of unexpected large-scale changes to the price level and the resulting financial consequences. The component of inflation expectations was skillfully emphasized in the foregoing passage. Money does not lose its value in a manner which would be perceptible for the owners. Then the rate of depreciation of a monetary unit is very low, almost unnoticeable to an ordinary citizen of the given 
country or foreign investors. For $2 \%$ inflation, as calculated on an annual basis, the rate of currency depreciation equals $1.96 \%$, whereas in the case of $3 \%$ inflation this rate of current depreciation is $2.91 \%$. For the sake of comparison, when the inflation rate is very high, e.g. annually coming to $50 \%$, the currency depreciation rate will equal as much as $33.33 \%$. At this point, it should be added that for the American central bank, price stability does not only matter in itself, but its importance for the Fed is crucial in terms of performance of the dual mandate resulting from the relevant act.

A direct reference to the manner in which the category of price stability was understood by A. Greenspan many years ago can be found in an article entitled Stable Prices, Stable Economy. Keeping Inflation in Check Must Be No. 1 Goal of Monetary Policymakers published in January 2008. Two American economists who were or are affiliated with the Federal Reserve Bank of St. Louis believe that price stability is equivalent to inflation being low and stable to the point that it does not affect economic decisions of businesses and households. When inflation is low enough for a sufficiently long period of time, people do not waste their resources to protect themselves against inflation and its negative effects. It is then that they are willing to both invest and save, since they are convinced that money will not lose its value for a long period of time (Poole, Wheelock 2008).

Under conditions of creeping inflation, there is typically no problem protecting the value of money, since the interest rate on such financial products offered by banks and issuers of debt instruments as traditional deposits or corporate and municipal bonds makes it possible to maintain the purchasing power of previously accumulated savings. At the same time, it does not generate any new stimuli for radical change of the market players' conduct, because it simply triggers no concerns about severe loss of the purchasing power of money emerging as time passes. Furthermore, the information function of prices under conditions of low and stabilized inflation is attained and performed in a sufficient manner, there is no intensification of uncertainty in the actions undertaken by investors and consumers, 
and no significant disturbances to the economic activity is observed. ${ }^{3}$ It is relatively easy to distinguish between changes to individual prices of goods and services occurring under the impact of the law of supply and demand observed in individual fragmentary markets and those triggered by a change in the general level of prices. This enables markets to allocate resources to individual industries and sectors of economy characterized by the highest profitability more efficiently.

The two aforementioned economists from the Federal Reserve Bank of St. Louis, W. Poole and D. Wheelock, perceive price stability in the following manner:

"Price stability is usually interpreted to mean a low and stable rate of inflation maintained over an extended period of time. [...] The ideal rate of inflation is zero, properly measured. Biases in price indexes imply that, in practice, price stability will likely be consistent with a small positive rate of measured inflation, [...] depending on the specific price index [...] price stability does not mean that the price index is constant. Monetary policy could never eliminate every wiggle in the inflation rate; nor should policymakers try to do so" (Poole, Wheelock 2008).

What matters particularly in this respect is the observation that price stability is not equivalent to a constant price index. Moreover, monetary policy will never succeed in eliminating all inflation rate fluctuations, and therefore, those responsible for managing it should not attempt to do so. Other aforementioned elements are rather typical, i.e. low and stable inflation rate maintained for an extended period of time.

The National Bank of Austria (Die Oesterreichische Nationalbank - OeNB), on the other hand, understands the nature of price stability as follows:

"Das Ziel der Preisstabilität bezieht sich auf das allgemeine Preisniveau in der Volkswirtschaft und bedeutet, dass sowohl andauernde und hohe Inflation als auch Deflation vermieden werden. Preisstabilität trägt auf verschiedene Weise zu einer lebhaften Wirtschaftsaktivität und einem hohen Beschäftigungsstand bei. Die Vorrangigkeit des Ziels der Preisstabilität in der Geldpolitik reflektiert den breiten Konsens in der Ökonomie, dass Geldpolitik reale Größen in der Wirtschaft [...] nur kurzfristig beeinflussen kann, aber langfristig darauf keinen Einfluss hat" (OeNB 2016).

\footnotetext{
${ }^{3}$ In case of high inflation, the information function of prices quickly becomes distorted, and one observes increasing uncertainty and impairment of economic activity, intense redistribution of income and assets as well as growing phenomenon of what is referred to as money flight.
} 
("The goal of price stability relates to the general price level in the economy and means that both persistent and high inflation and deflation are avoided. Price stability contributes to brisk economic activity and high employment in different ways. The priority of the goal of price stability in monetary policy reflects the broad consensus in economics that monetary policy can only influence real variables in the economy [...] in the short term, but has no influence on them in the long term.")

In such a perspective, price stability refers to the general level of prices in the economy, which means that both prolonged high inflation and deflation should be avoided. Price stability may differently contribute to the revival of economic activity, at the same time being favourable to high level of employment.

Price stability in the eurozone was very precisely defined by the European Central Bank. In 1998, the ECB's Governing Council ${ }^{4}$ formulated a quantitative definition of price stability which reads as follows:

"Price stability is a year-on-year increase in the Harmonized Index of Consumer Prices (HICP) for the euro area of below $2 \%$. Price stability must be maintained over a medium-term perspective" (ECB 2016).

This definition was made even more precise five years later (May 2003). The following passage was added:

"In the pursuit of price stability, it aims to maintain inflation rates below, but close to, $2 \%$ over the medium term."

The European Central Bank clearly stresses the need for maintaining price stability, as it is considered the fundamental goal of the Community's monetary policy and of the entire Eurosystem. There is a dedicated provision in the treaty (article 127) which highlights its superior rank, attaching primary importance to price stability. It is clearly stated that price stability plays the most important role in terms of the contribution of monetary policy to attaining favourable economic conditions and high employment rate.

M. Noga, a former member of the Monetary Policy Council ${ }^{5}$ of the second term of office (2004-2010), has proposed a very clear, concise and informative definition

\footnotetext{
${ }^{4}$ The ECB was founded on 1 June 1998.
} 
of the fundamental goal of monetary policy implemented by the central bank of Poland, stating that "it is commonly recognized that a central bank's main goal is to provide for price stability in the given country" (Noga 2012: 102). This economist also refers to article 3 of the act on the National Bank of Poland (NBP) of 1997 which reads: "the basic objective of the activity of NBP shall be to maintain price stability, while supporting the economic policy of the Government, insofar as this does not constrain the pursuit of the basic objective of NBP." Price stability is one of the most significant categories and notions of the Polish monetary policy, defined directly in the act on the central bank.

In the latest official document released by the National Bank of Poland, namely the Monetary Policy Guidelines for 2016, price stability has been defined as follows: "Nowadays central banks define price stability as low, yet positive inflation, which does not adversely affect the decisions of economic agents, including investment and savings decisions. Price stability may be threatened not only by excessive inflation, but also by persistent deflation, especially if accompanied by slow economic growth or stagnation" (NBP 2015). The foregoing definition contains elements which directly refer to the price stability definition formulated by A. Greenspan in the mid-1990's. A few years later Federal Reserve Chairman A. Greenspan stated that "price stability is best thought of as an environment in which inflation is so low and stable over time that it does not materially enter into the decisions of households and firms" (Greenspan 2002). This is a fairly common definition of price stability, and it has two essential characteristics. First, actual inflation must remain low and stable, and second, people must have confidence that inflation will remain low and stable. This second characteristic may not get as much emphasis as it deserves. Price stability is more than keeping inflation in check - it also means keeping inflation expectations in check. They have been laid down in more detail, emphasizing the symmetrical threats to price stability posed by both excessive inflation and persistent deflation. The expression "low, yet positive inflation" used in the NBP's definition is understood in this respect as open inflation of moderately intensified force of acceleration in time, without the destructive potential of price increase which might become activated with large force in the

\footnotetext{
${ }^{5}$ Rada Polityki Pieniężnej.
} 
future. An equation mark may be placed between it and creeping inflation of low intensity, characterized by a rather limited increase of the average price level in the economy, one which does not exceed $2-2.5 \%$ over an annual period. Inflation of such characteristics, without clearly distinguishable peaks in the amplitude of changes, is currently treated as a normal phenomenon of economy, since neither does it cause discernible perturbations in the market mechanism and its functioning, nor triggers any negative economic effects. As time passes, the price level rises at a relatively low rate, posing no threat to the given country's macroeconomic stability and economic growth dynamics.

In mid-December 2015, the NBP's head office hosted a scientific conference summarizing the ending $3^{\text {rd }}$ term of office of the Monetary Policy Council (20102016). In his speech, NBP's President M. Belka stressed that "it is a success of the NBP and all the previous Monetary Policy Councils that inflation in Poland has remained stable and low for years, as it does not exert any negative impact on macroeconomic processes and citizens are not faced with the painful price increase in their everyday life. By that means, the Council achieves its main goal, namely the pursuit of price stability" (NBP 2016). Uninterruptedly for 18 years (since 1998), the National Bank of Poland has implemented monetary policy which ensures long-term price stability to the national economy. The mean inflation rate in the years 20042010 , measured with reference to CPI, came to $2.8 \%$, whereas within the last six years, it equaled $1.8 \%$. In both these cases, the average rate of price changes corresponded to the NBP's mid-term inflation goal $(2.5 \% \pm 1$ percentage point). Moreover, the National Bank of Poland has consistently supported macroeconomic balance and efforts aimed to maintain stability of the financial system, particularly after the global economic crisis outbreak.

To recapitulate the foregoing, a decided majority of definitions and descriptions of price stability proposed in publications elaborating upon central banking and monetary policy as well as in various reports and expert's papers are understood in a similar, if not identical manner. What remains an issue open for discussion is how to interpret it: as a more or less extensive description assuming the form of a characteristic of stabilized creeping inflation or even a reference to a specific base value of the price change rate on an annual basis. Frequently quoted definitions of 
price stability, on account of their purely descriptive nature, lacking any direct reference to the price index, find very limited practical application for obvious reasons.

The ultimate goal of monetary policy in highly developed countries is usually defined as an annual inflation rate being positive, yet not higher than $4 \%$. The countries where the DIT strategy has been deployed define and publicly announce the numerical value of the target, and by that means they establish how price stability is understood in quantitative terms. The gist of the problem is exactly the pre-set target, without any permissible deviations.

Striving to achieve the assumed final goal of monetary policy, the central bank potentially supports maintaining long-term stable and sustainable economic growth, creating favourable conditions in the monetary dimension by ensuring mid- and long-term price stability. It is then far easier and more efficient to implement social and economic programmes as well as to perform all tasks assigned to the central body which manages the economic policy compared to acting under conditions of developing inflation processes or persistent deflation trends. That is why both price stability as well as its relentless institutional advocate and promoter, i.e. the central bank, play such a crucial role in economic processes. The benefits of maintaining price stability in the economy are multi-faceted and undisputable, and the following are the most important ones (Błaszczyk 2010):

- Price stability helps to improve the transparency of the price mechanism. Under price stability people can recognize changes in relative prices, without being confused by changes in the overall price level. This allows them to make wellinformed consumption and investment decisions and to allocate resources more efficiently;

- Price stability helps to reduce inflation risk premia in interest rates. This reduces real interest rates and increases incentives to invest;

- Price stability helps to avoid unproductive activities to hedge against the negative impact of inflation or deflation;

- Price stability helps to reduce distortions of inflation or deflation, which can exacerbate the distortionary impact on economic behaviour of tax and social security systems; 
- Price stability helps to prevent an arbitrary redistribution of wealth and income as a result of unexpected inflation or deflation.

Price stability is the indispensable and well-proven ultimate goal of monetary policy, irrespective of the subtle differences connected with its definition and interpretation. The above observation is by no means exaggerated, but it rather constitutes a confirmation of the price stability's invaluable importance in ensuring high economic activeness of contemporary societies, which has evidently been empirically proved (Beyer, Reichlin 2006). The following statement by B. Bernanke, at that time a candidate running for the nomination to the office of the Fed's head (15 November 2005), delivered before the Committee on Banking, Housing and Urban Affairs of the U.S. Senate, confirms the foregoing:

"...central bankers in the United States and around the world have come to understand that ensuring long-run price stability is essential for achieving maximum employment and overall economic stability. In recent decades, the variability of output and employment has decreased markedly, and recessions have been less frequent and less severe. I believe that the Federal Reserve's success in reducing and stabilizing inflation and inflation expectations is a major reason for this improved economic performance. If I am confirmed, I am confident that my colleagues on the Federal Open Market Committee (FOMC) and I will maintain the focus on long-term price stability as monetary policy's greatest contribution to general economic prosperity and maximum employment" (Bernanke 2005).

\section{Concluding remarks}

In the contemporary market economy, the primary goal of monetary policy is price stability, being commonly understood as the central bank's effort to maintain low inflation over the medium term. Nevertheless, in the mid-term perspective, the monetary authority cannot guarantee a relatively low, yet positive inflation rate for various reasons, including the fact that many factors, both internal and particularly external in nature, affecting the level as well as the course of inflation in time, remain beyond its control. In this day and age, the level of inflation in a given country is heavily affected by various stimuli and impulses imposed by the global 
economy. The foregoing is an outcome of globalization processes, strongly intensifying over the last two decades (IMF 2005). There are well known cases of strong multidirectional pressure of external supply factors exerting their influence by means of imported inflation, as it is commonly referred to. They can significantly raise or reduce the inflation rate in the national economy (Forbes 2019).

The discourse in the mid-1990's concerning the choice of suitable goals of monetary policy ended with a consensus. The central bank's fundamental goal is price stability understood as equivalent to low inflation, less than ten per cent at the most on an annual basis, pursued over a mid-term horizon. Almost by nature, this solution rejects the competitive goal of price level constancy which would correspond to zero-level inflation. Bearing in mind the difficulties connected with appropriate estimation of the inflation rate, as highlighted by the Boskin Commission (1996), actual inflation could even frequently be negative, indeed tuning into the most genuine form of deflation.

Ultimately, the fact that it is none other than low inflation which has become the most reasonable purpose of monetary policy is caused by practice rather than by theory. What played the leading role in this respect was the intense inflation processes which dominated the global economy of the 1970's and the first half of the 1980's in the aftermath of the first and the second oil shock. Also the visionary concept promoted by the president of Bundesbank, O. Emminger (see Schneider 2007), claiming that price stability was not everything, but without price stability, everything was nothing, became commonly accepted. Its very essence has been expressed in practical terms in the quantitative definition of the European Central Bank's goal.

The following quotation seems appropriate to recapitulate the above analysis in the most concise and compact manner: "Price stability is the most powerful tool the central bank has to promote economic growth, high employment and financial stability. Price stability also enables monetary authorities to pursue secondary objectives, including the reduction of fluctuations in real economic activity and the management of financial and/or liquidity crises" (Poole, Wheelock 2008: 3). The foregoing is the very essence of the efforts undertaken by the central banks as a means to improve the manner in which the economy functions over a mid- and long- 
term period as the fundamental goal of monetary policy, namely price stability, is pursued. The contemporary indicators of good standing of a market economy include high long-lasting and sustainable economic growth, high employment rate, low inflation rate and financial stability of the system. It is for the price stability that monetary authorities can make their immensely important contribution to the activities aimed at reducing the scale of inevitable fluctuations in the real sphere, assuming the form of variations in production volumes and employment.

Price stability, being the target for which the central bank relentlessly strives on account of its major anti-inflation mission, is also particularly favourable to the struggle against economic, banking and liquidity-related crises. Under normal macroeconomic conditions, leaving aside a clearly extreme situation, which both the global economic mega-crisis of the years 2008-2009 and its prolonged consequences evidently were, one may conclude that there is essentially no alternative goal to price stability in monetary policy. Price stability promotes efficiency and long-term growth by providing a monetary and financial environment in which economic decisions can be made and markets can operate without concern about unpredictable fluctuations in the purchasing power of money.

\section{References}

Banco de Portugal (2017), What is it and how does it work?, https://www.bportugal.pt/en/page/monpolwhat-is-it [10.09.2017].

Barsky R.B., Kilian L. (2002), Do we really know that oil caused the Great Stagflation? A monetary alternative, NBER Macroeconomics Annual, pp. 137-183.

Barsky R.B., Kilian L. (2004), Oil and the macroeconomy since the 1970s, "Journal of Economic Perspectives", vol. 18 no. 4, pp. 115-134.

Bernanke B. (2002), Deflation: making sure "it" doesn't happen here, https://www.federalreserve.gov/boarddocs/Speeches/2002/20021121/default.htm [23.05.2017].

Bernanke B. (2004), The Great Moderation, www.federalreserve.gov/boarddocs/speeches/2004/20040220/ [10.05.2017].

Bernanke B. (2005), Nomination hearing before the Committee on Banking, Housing, and Urban Affairs, U.S. Senate, https://www.federalreserve.gov/boarddocs/testimony/2005/20051115/default.htm [20.05.2017]. 


\section{THE PRIMARY GOAL OF MONETARY POLICY: REFLECTIONS ON THE NATURE ...}

Bernanke B. (2006a), Semiannual Monetary Policy Report to the Congress, https://www.federalreserve.gov/newsevents/testimony/bernanke20060215a.htm [12.05.2017].

Bernanke B. (2006b), The benefits of price stability, https://www.federalreserve.gov/newsevents/speech/bernanke20060224a.htm [13.07.2017].

Beyer A., Reichlin L. (2006), The role of money - money and monetary policy in the twenty-first century, European Central Bank, https://www.ecb.europa.eu/pub/pdf/other/roleofmoneyen2008en.pdf [17.08.2017].

Blanchard O. (2011), Makroekonomia, Oficyna a Wolters Kluwer Business, Warszawa.

Błaszczyk P. (2010), Stabilność cen - sposoby definicji oraz wyzwania dla polityki pieniężnej, “Materiały i Studia NBP”, vol. 249, https://www.nbp.pl/publikacje/materialy_i_studia/ms249.pdf [15.06.2017].

Bronfenbrenner M. (1976), Elements of stagflation theory, "Zeitschrift für Nationalökonomie / Journal of Economics", vol. 36 no. 1-2, https://www.jstor.org/stable/41797816?seq=1 [22.08.2017].

Ciżkowicz-Pękała M., Grostal W. (2019), Three decades of inflation targeting, NBP Working Paper no. 314, https://www.nbp.pl/publikacje/materialy_i_studia/314_en.pdf [12.12.2020].

Duisenberg W.F. (2001), The ECB's quantitative definition of price stability and its comparison with such definitions or inflation targets applied in other large economic areas, https://www.ecb.europa.eu/press/key/date/2001/html/sp011016_2.en.html [15.05.2017].

ECB (2016), The definition of price stability, https://www.ecb.europa.eu/mopo/strategy/pricestab/html/index.en.html [01.07.2017].

Eckstein O., Sinai A. (1986), The mechanisms of the business cycle in the postwar era, in: American business cycle. Continuity and change, Gordon R.J. (ed.), University of Chicago Press, Chicago, https://www.nber.org/system/files/chapters/c10020/c10020.pdf [18.06.2017].

Fischer S. (1984), The benefits of price stability, https://dspace.mit.edu/bitstream/handle/1721.1/63425/benefitsofprices00fisc.pdf?sequence=1 [18.08.2017].

Forbes K.J. (2019), Has globalization changed the inflation process, BIS Working Paper no. 791, https://www.bis.org/publ/work791.pdf [10.01.2020].

Friedman M. (1969), The optimum quantity of money, Macmillan, London.

Gadomski W. (2014), Obawa przed deflacją jest przesadzona, www.obserwatorfinansowy.pl/tematyka/makroekonomia/obawa-przed-deflacja-jest-przesadzona [30.06.2017].

Goodfriend M. (2007), How the world achieved consensus on monetary policy, NBER Working Paper no. 13580, https://www.nber.org/system/files/working_papers/w13580/w13580.pdf [20.05.2017].

Greenspan A. (1994), Semiannual Monetary Policy Report to the Congress. Testimony before the Subcommittee on Economic Growth and Credit Formation of the Committee on Banking, Finance and 


\section{Adam HETMAŃCZUK}

Urban Affairs, U.S. House of Representatives, https://fraser.stlouisfed.org/title/statements-speechesalan-greenspan-452/semiannual-monetary-policy-report-congress-8500 [16.08.2017].

Greenspan A. (1996), Meeting of the Federal Open Market Committee, July 2-3, https://www.federalreserve.gov/monetarypolicy/files/FOMC19960703meeting.pdf [15.05.2017].

Greenspan A. (2002), Transparency in monetary policy, "Federal Reserve Bank of St. Louis Review", July/August https://research.stlouisfed.org/publications/review/2002/07/01 [12.08.2017].

Harris E. (2009), Fed Bena Bernanke. Bank Rezerwy Federalnej po Greenspanie, Wydawnictwo Studio EMKA, Warszawa.

Heller R. (2015), The Fed versus price stability, https://www.project-syndicate.org/commentary/fedinflation-target-by-robert-heller-2015-03?barrier=true [28.05.2017].

Lars E.O., Svensson L.E.O. (1999), Price stability as a target for monetary policy: defining and maintaining price stability, NBER Working Paper no. 7276, https://www.nber.org/system/files/working_papers/w7276/w7276.pdf [17.06.2017].

Lowenstein R. (2019), How Paul Volcker beat inflation and saved an independent Fed, The Washington Post, https://www.washingtonpost.com/business/economy/how-paul-volcker-beatinflation-and-saved-an-independent-fed/2019/12/10/7e58d7ae-1b64-11ea-87f7-

f2e91143c60d_story.html [20.12.2019].

Lucas R. (1972), Expectations and the neutrality of money, "Journal of Economic Theory", vol. 4 no. 2 , pp.

103-124, http://citeseerx.ist.psu.edu/viewdoc/download?doi=10.1.1.592.6178\&rep=rep1\&type=pdf [12.09.2017].

Lucas R. (1983), Studies in business-cycle theory, The MIT Press, Cambridge.

NBP (2004), Europejski system banków centralnych, www.nbp.pl/publikacje/esbc/esbc [19.06.2017].

NBP (2015), Założenia polityki pieniężnej na rok 2016, https://www.nbp.pl/polityka_pieniezna/dokumenty/zalozenia/zalozenia_pp_2016.pdf [18.08.2017].

NBP (2016), Stabilność cen i równowaga makroekonomiczna. Rada Polityki Pieniężnej kończy sześcioletnią kadencję, http://www.nbp.pl/aktualnosci/wiadomosci_2015/rpp_2015_12_15.html [10.06.2017].

Noga M. (2012), Makroekonomia ze szczególnym uwzględnieniem polityki pieniężnej, CeDeWu.Pl, Warszawa.

OeNB (2016), Warum Preisstabilität, www.oenb.at/Geldpolitik/Ziele-der-Geldpolitik/WarumPreisstabilitaet [15.08.2017].

Poole W., Wheelock D. (2008), Stable prices, stable economy. Keeping inflation in check must be no. 1 goal of monetary policymakers, https://www.stlouisfed.org/publications/regional-economist/january2008/stable-prices-stable-economy-keeping-inflation-in-check-must-be-no-1-goal-of-monetarypolicymakers [6.08.2017]. 


\section{THE PRIMARY GOAL OF MONETARY POLICY: REFLECTIONS ON THE NATURE ...}

Przybylska-Kapuścińska W. (2008), Współczesna polityka pieniężna, Wydawnictwo Difin, Warszawa.

Przybylska-Mazur A. (2013), Reguły polityki pieniężnej a prognozowanie wskaźnika inflacji, "Studia Ekonomiczne / Uniwersytet Ekonomiczny w Katowicach”, no. 124, pp. 233-244.

Rhys D.G., Barry D. (1976), The current inflation. Causation and mechanics, https://www.emerald.com/insight/content/doi/10.1108/eb013791/full/html?skipTracking=true [15.06.2017].

Roubini N., Mihm S. (2011), Ekonomia kryzysu, Oficyna a Wolters Kluwer Business, Warszawa.

Schneider K. (2007), Die Bank der Banken. Die Deutsche Bundesbank wird 50 Jahre, www.wissen.de/die-bank-der-banken [18.07.2017].

Snowdon B., Vane H., Wynarczyk P. (1998), Współczesne nurty teorii makroekonomii, Wydawnictwo Naukowe PWN, Warszawa.

Steelman A. (2011), The Federal Reserve's "dual mandate". The evolution of an idea, Federal Reserve Bank of Richmond, https://www.richmondfed.org/publications/research/economic_brief/2011/eb_1112 [28.08.2017].

Teutsch O. (2007), 50 Jahre Bundesbank. Eine deutsche Erfolgsgeschichte, http://www.spiegel.de/wirtschaft/50-jahre-bundesbank-eine-deutsche-erfolgsgeschichte-a-497250.html [24.08.2017].

The Economist (2006), Running on M3, The Economist, https://www.economist.com/leaders/2006/03/23/running-on-m3 [28.06.2017].

The Economist (2010), The Volcker recession. Who beat inflation?, The Economist, www.economist.com/blogs/freeexchange/2010/03/volcker_recession [11.06.2017].

White W.R. (2006), Is price stability enough?, https://www.bis.org/publ/work205.pdf [18.06.2017]. 